\title{
Russian Animalier Art in the XVIII- XIX Centuries in the Context of European Schools: The Origins and Nature of Development
}

\author{
Irina V. Portnova ${ }^{\dagger}$
}

\section{Abstract}

This study delves into the process of development of Russian animal art of the 18th-19th Centuries. The primary purpose of the research was to make a review of these two historical periods, which determined the typical features of the early and mature periods of development of animal art in Russia - the time of the birth and development of the genre. According to the author, genre issues are important, and talking about it is necessary to define the image of the animalistic nature in all its specificity. In addition, it is noted that researchers do not characterise the stage of early Animalism, which first appeared in the 18th Century, sufficiently. Nevertheless, this genre has demonstrated all the love of artists for the real perception of the natural world and their sincere will to create its truthful and reliable reflection in their works. This tendency is typical for Western European Art. At the same time, it has been explicitly expressed in the works of Russian animal artists. Compared with European Animal Art of the 17th-18th Centuries, Russian 'Kunstkammer drawing' and how the class of 'animal and birds' was organised looked like a real innovation. These two factors have contributed to the creation of a full-fledged animalistic image. The author underlines that the main principle of imitation of nature was at the basis of teaching in the Russian school. It eventually led to the formation of the genre with its complex, distinctive features. These unique features was observed in the animal art of the 19th Century, mainly in the form of hippique images.

Nevertheless, there was an attempt to combine two separated historical periods - the 18th and 19th Centuries, which demonstrated different images, approaches (animal naturalia of the 18th Century and horse characters of the 19th Century). The author, here, tends to talk about Russian Animalism of the 19th Century, one of the most explored ones. Doing so underlines the importance of animal art of the two periods as a historically conditioned cultural phenomenon in the relationship between genres of Fine Art and trends of the time. The historical and artistic method made it possible to identify the connection between these two eras in which Animalism was expressed significantly. Its originality is that it combined two diverse eras into one national whole.

Keywords: Animalier Art; Animal World; Art Forms; Custom Work; Drawings-Illustrations; Foreshortening; Natural Environment; Poses

\footnotetext{
${ }^{\dagger}$ Associate Professor, Peoples' Friendship University of Russia. Department of architecture Engineering Academy. 11719 Moscow, Russia, Email: irinaportnova@mail.ru

(C) 2021 Portnova. This is an Open Access article distributed under the terms of the Creative Commons Attribution License (http://creativecommons.org/licenses/by/2.0), which permits unrestricted use, distribution, and reproduction in any medium, provided the original work is properly cited.
} 


\section{Introduction}

Russian animalistic Art of the XVIII - XIX Centuries is a holistic phenomenon that reflects the general direction and trends of the fine arts of the time under consideration. A significant achievement was the formation of genre features, closely associated with the emergence of Modern Times Art in Russia. Consideration of the genre aspects of animal art in its historical development, which will allow to examine its specific features among other genres of Russian fine arts, is the novelty of the study. The study emphasises the genre features of the initial period of Russian animalier arts as an essential basis for its subsequent development. This approach allows seeing a picture of the being of Russian Animalier Arts of two Centuries, starting with its birth and further forming the genre features. Western European and Russian authors wrote about the Art of Animalism. They talked about Animalism as interesting and fruitful in their monograph essays, articles, and notes on exhibitions. Researchers willingly covered the history of world animalistics, from antiquity to our days. They are interested in the artistic characteristics of the embodied image of great historical epochs, for example, classical antiquity or classicism, the romanticism of the XVIII - XIX Centuries. Books by Jocelyn M. Toynbee (Toynbee 2011:431; see also, Beime, 2015144) are among them. For example, considering the Animalier Art of Ancient Rome, M. Jocelyn turns to iconographic principles of depicting animals as a long-used technique to highlight and emphasise the significance of certain characters in society. Describing animals, Hope B. Wemess (2006:476) deals with the question of what people think about them. In his opinion, the ways people depict them talk about using multiple metaphors in the world of cultures. Paul Waldau \& Kimberley Patton (2006:720) writes about how beliefs, myths and rituals related to animals were included in the main religious systems. They note the important culturological layer in the relationship between man and animals in the context of the social reality in which we live. An animal in postmodern currents (Baker, 2007:208) is regarded as a link, a part of the modern world order, capable of revealing new themes and ideas. The idea of ecology, which to a large extent was also covered in the writings of Russian authors, is also important. This universal concept of saving the natural world that had become universal, has opened a new layer of the Animalier Art importance. Continuing the conversation about the place and role of animals in the human society, Linda Kalof (Kalof, 2009:261) examines the important era of the Renaissance. She explores a wide range of topics related to changes in views on living nature, and their interpretations in Art, ranging from religious symbolic images of animals and ending with different anatomical models. Rosa Giorgi has illustrated this kind of painting in her book (Giorgi, 2008:383), where the author speaks about the specialisation of the Dutch artist of the XVII Century, Paulus Potter, in the field of engraving and drawing animals, the talks about them "like real." Talking about the Art of depicting animals, Mare G. Morton, Colin B. Bailey, in their "Oudry's painted menagerie: portraits of exotic animals in eighteenth-century Europe" (Morton \& Bailey, 2007:168) consider the work of the French animalier Jean-Baptiste Oudry, who painted wild animals in the royal menagerie of Louis XV at Versailles. Similarly, Nathaniel Wolloch (Wolloch, 2017:280) examines the attiudude to animals in Western culture, the role of animals in early anthropomorphic literature and their portrayals in Dutch and Flemish painting. He rightfully links these historical tendencies with the discussion of the question of the "rights" of animals and the environmental problems of modern society. Louise Lippincott (Lippincott, 2005:160) distinguishes the Enlightenment era as a difficult period. The philosophical legacy of the enlightenment era, the impact of the industrial revolution and the intellectual transformation caused by Charles Darwin, brought about cardinal changes in the minds of thinkers, undermined many traditional foundations and brought new meaning, in particular 
understanding the importance of the common biological origin of man and animals. The author explores how artists, sculptors, illustrators reflected modern changes in the perception of animals, including in their work the latest developments in the field of geographic research and comparative anatomy, achievements in geology and the birth of palaeontology, the influence of the theory of evolution. The importance of illustrators, amateur naturalists, who were often at the forefront of discoveries of natural history, is determined. Such different artists as Oudry, Delacroix, Gericault, Hogarth, and others often included images of animals in historical, genre, portrait, landscape painting. Analysing the works of English artist William Hogarth, containing images of domestic animals, Beime (2015) touches on the problem of the emblematic and symbolic essence of the animalistic image.

In general, publications tend to cover a diverse range of issues that reflect interests of fine arts in the field of knowledge of nature and animals. We can underline the ancient images and the image of animals of significant historical eras. As one can witness, the scholars willingly talk about the essence of nature, animals and their images in different cultures and discuss environmental issues. These arguments demonstrate the scholars' interest in this universal topic reflected in the classical and new Art. Within the limits of this reasoning, researchers still insufficiently characterise the genre of Animalism. They do not consider the question of whether any image will be the animalistic one or not. This question comes to mind because images of animals in different types of fine Art are modified. Only in the purity of the figurative characteristic an animal can be called animalistic, which is vital in the sense of understanding the very nature of the animalistic image, its structure and specificity. Thus we believe that discussing the genre is very important. It is an indicator of a certain formulation of human views on the animal world and an artistic concept of time. I.F. Urvanov (Urvanov, 1793: 48) was really into this issue, first of all, due to the organisation of the Russian Academy of Arts in St. Petersburg.
The author had successfully shown the role of Russian animal painting of the 18th Century and its place in the Fine Art genre system, which were entirely defined as independent ones at that time.

Urvanov (1793) showed a combination of special 'genera' in Russian Fine Art of the XVIII Century and has defined 'animal painting' as a separate 'genus' of painting in interaction with other genres. He noted that the transfer of a reliable image of animals and birds was characteristic of Animalism. Images of animals were met in different genres of Fine Arts and were included in the curriculum of academic education. Describing the 'battle', 'landscape' painting, Urvanov (1793) indicated in it that animals' image should be 'known', that is "drawn from different images of famous animals, plants and flowers"(1793:45 ), as well as from nature. These provisions have also been reflected in the literature of the XIX Century, in particular in the works of the Imperial Academy of Arts. The value of these sources, which contain information about the work of the masters, the stages of their training, their fulfilment of the prescribed academic assignments, the organisation of academic exhibitions, etc., also consists in the fact that they stood at the origins of the Russian Animalistic genre. In addition, it was in the academic environment that many animal artists of the XVIII - XIX Centuries emerged.

At that time, the yet rare articles about XVIII Century Animalier art were of a specific significance, and most of animaliers were German artists. So, V. Petrov wrote about J.E. Ridinger, J.F. Grooth, K.F. Knappe (Petrov, 1864:19), A.N. Andreev about J.F.Grooth (Andreev, 1857:17), and D.A. Rovinsky wrote about J.S. Klauber (Rovinsky, 1985:720). The authors called the artists skilful masters who have reached the heights of creativity, and the Art of 'Animal Painting' was labelled as a special 'genus.'

Creativity sculptor animaliers, P.K. Klodt, N.I. Liberich, A.L. Ober, was viewed in magazines: literary-World illustration, artistic and historical-Russian Art Archive, historical and literary-Russian Archive, artistic-The Old 
Years. Indeed, the first illustrated catalogue of the Russian Animaliers of the XIX Century sculpture exhibition was published in 1886. In general, publications tend to embrace a diverse range of issues reflecting the interests in the field of Fine Arts of the XVIII - XIX Centuries, referring to the sphere of cognition of nature and animals. The XX century is marked by the popularisation of the animalistic genre in the broad masses. The publications about P. Klodt (Romm, 1948:27; Rubtsov, 1950: 38,39,42), E. Lansere (Schmidt, 1954:30, see also, Archive 652. Unit 718. Sheet 4.) are especially interesting. They give a description of the various aspects of the sculptors' work, emphasise the professionalism, and most importantly, they attempt to summarise the achievements of Russian animalistic sculpture of the first and second half of the XIX Century.

During the period of 1990-2000, new studies appeared on the origins of Russian Animalism, especially via the works of foreign artists who worked in Russia. Among publications, the work by L. Markina (Markina, 1999:109) may be mentioned, which characterises the J.F. Grooth 'animal painting' creativity. She assigned German masters a prominent role in the training of Russian artists and the formation of the animalier genre.

We dwell in two historical stages in the development of Animalism: the 18th Century the time of formation of the genre, which acquired a shape of structural features and the 19th Century, which has established itself as a genre with great potential, primarily in the field of hippique images (image of a horse).

The timelines of this study is defined by the fact that the consideration of the origins and specific features of Russian animalistics of the XVIII - XIX centuries enriches Russian Art with a new look at the specificity of the genre and its value at the present stage in the context of global world environmental problems when the main principle of the relationship between man and nature is reassessed. Against this background, the study of the problems of Russian animalier art is quite timely.
The materials presented in the study represents the value for art criticism, enriching Art with new research and little-known facts as a road to enlightening pedagogy and in a broader philosophical sense, posing a number of moral issues.

\section{Peculiarities Of Russian Animalier Art Development In XVIII -XIX Centuries}

The study's objective is to demostrate the general laws of the given process in the context of time, which makes it possible to compile the most holistic view of the animalistic genre and the scale of its development. Analysis of the genre features of Russian animal studies assumes consideration of the concept of an animalistic image as a model of new Art that has developed into an independent genre. In the XVIII Century, animal studies gained some stability through the installation of visual culture in imitation of nature. It was the epoch, with its pronounced need for cognition of the surrounding world (scientific research, geographic travel, etc.), that contributed to the emergence of graphic and pictorial images of a variety of animals and birds.. Significantly, at that time, the main genres of Fine Art (historical, battle, portrait, landscape, still life) were formed in their structural and artistic features, in the structure of which the Animalism was organically incorporated. In this structure, it appeared on the last steps of the hierarchical ladder, sharing places with landscape and still life. Nevertheless, being included in the themes and plots of other genres, diversifying the motives, sometimes even introducing an entertainment element into it; through the use of specific features, the history of development was affirmed in its characteristics. . Already at an early stage, the transfer of a reliable image of animals and birds were the characteristic features of Animalistic Art.

In the Petrine era, the first scientific Kunstkamera museum was established, which contributed to the birth of a scientific Kunstkamera drawing. Artists who worked in Kunstkammer are Maria Sybilla Merian, J.C. Buxsbaum, Georg Gsell and Maria Dorothea Gsell. In addition, the students under the 
direction of J.E. Grimmel in the engraving chamber of the Academy of Sciences performed detailed drawings and illustrations of naturalem visual aids for the museum, which served as necessary reference tools. There are watercolour drawings of plants and insects of a German artist of the XVIII Century in the museum. Entomologist, book illustrator, publisher of the Metamorphosis Insectorum Surinamensium (1705), Maria Sibylla Merian, purchased Kunstkamera. There are drawings of the husband Gsell couple, Georg and MariaDorothea, who at the invitation of Peter I worked in the Academy of Sciences; botanical sketches of the German naturalist J.C. Buxbaum, who became the first academician-botanist of the Academy of Sciences recommended by Peter to describe the Russian flora.

The perception of the nature by a human, which is substantive and evaluative, is perceived holistically in the synthesis of various properties, has become an essential principle of its reflection. Approaching the drawing-analysis of nature selectively, the artists tried to assess the features of objects, which required a particular experience in a certain sense. For the most part, the comprehension of the subject was based on empirical experience and consisted in giving an accurate idea of the museum exhibit. In the course of practice, special regulations were developed: to sketch objects in full size or indicate the scale of the image and the dimensions. The subject in the figure should have an external similarity with nature, just as it was presented in the exposition (Kopaneva, 2006:58-77). So, botanist Buxbaum, who went to Constantinople, had instructions "to make careful searches in the kingdoms of nature, choosing interesting objects." To do this, it was necessary to "diligently paint", (Sytin, 2003:93), which was followed religiously by Buxbaum and his draftsmen of the expedition, the painter Johann Christian Mattarnovi, and his assistant apprentice.

Dorothea Gsell, the first foreign paintress to come to Russia, and the first female teacher of drawing in Russia, was also recommended to "paint the Kunstkamera with diligence, after the classic techniques, with water-based paints, to decorate the study cabinet " (Tikhonov, 2004:26). With all the detail of the image, masters sought to transfer the volume. Particular attention was paid to the falling shadows, creating the illusion of separation of the object from its background and spatial location. This technique was not new. It was used in the manner of a "quodlibet", which was common in Western European and Russian painting of the first half of the XVIII century and contributed to the optical effect of perceiving the artefact as a real three-dimensional object. The purpose of such images is to convince the viewer that there is not a painting in front of him, but certain objects that themselves have value, acting as the second likeness of nature.

There are Russian still lifes, representing the first experience of depicting animals as a part of another genre (Still Life by G.N.Teplev, Still Life with Parrot and a Music Sheet, Still Life (1737, oil on canvas, The State Hermitage Museum). A miniature writing technique with subtle colourtone nuances and an accent on the smallest detail in visual form revealed this 'philosophy' of being. Here the Russian Masters clearly followed the Western European tradition of the XVII Century. In the mentioned works by G.N. Teplov, the presence of a parrot and an insect (a fly) along with other objects; and a detailed graphic and colour study of all forms were tuned to transmit illusions, effects of reality. Such a 'realistic' nature of painting was a characteristic of Dutch, German still lifes. An example is the canvases of a German artist of the XVII Century, Abraham Mignon, depicting luxurious bouquets of flowers. His Dutch contemporaries Jan Davidsz de Heem, Jan van Huysum, masters of decorative still lifes, were able to masterfully reflect all-natural realities: plants, fruits, animals, birds, and insects. Their refined, reminiscent enamel technique of painting, which allowed conveying the surrounding world decoratively and exquisitely, attracted to itself and formed a taste.

In the artistic process itself, let us single out the key problem of 'imitation of nature', in the structure of which two interrelated lines can be 
traced. The first line was- 'imitation'which was seen as a study of nature, which was still speculative in nature. The second one has to do with the very process of interpreting nature, its perception, as an important principle of reality reflection. On the one hand, the artists demonstrated the ability to visually fix the external sides of the model (subjective perception), on the other hand, they have shown some features that let abstract away from the nature, its analysis and generalisation, which allow us speaking about the formation of the concept of 'image', the birth of some 'wordimage' ordered in accordance to the laws of human perception. This is the natural way of forming the image, in which the principles of a new nature, imagery, consisting in assessing lines, tone, colour, etc., were developed. The artist, mastering his own experience of the physical properties of models, simultaneously comprehended the laws of their image.

This 'reality' fixed as 'naturalness', which laid in the structure of early animalistic images, turned out to be the most understandable and accessible, suited the tastes of Russian artists and customers. In addition, the experience of depicting animals, birds, insects in the still life was an important factor in the formation of Russian animal studies. Naturally interpreted animals in still lifes, in scientific drawings, perhaps, have served as some kind of Fine Art model for the next generation of animal artists. The masters of the middle, and then the second half of the XVIII Century, took the 'naturalness', the realism, as the basis of their creative solutions. In the process of studying the mechanisms of nature, the artists formed an aesthetic sensibility. Admiring 'naturalem' led to the fact that the artists, fixing the features of each form in imitation of nature as a real, really recognisable pattern, formed the standard of beauty, in which authenticity and accuracy became the measure of painting and drawing quality.

During the epoch of Elizabeth and Catherine, foreign artists (J.F Grooth, K.F. Knappe, I.S. Klauber) working at the court, performing a large number of orders, formed an interest in the
Animalier Art, introduced Russia with new styles. The very style of animalistic paintings of foreign artists, who gravitated towards the naturalness of the image, has proved useful in the matter of acquaintance of the Russian public with the animal world.

Collecting activity played a role in the development of Russian Animalier art. When the Museum Affairs emerged, beginning with the Petrine era, collecting works of Western European painting of the XVII - XVIII Centuries, through which Russian artists also got acquainted with new genres, themes, plots became commonplace. Since the dynastic connections of the Russian court, primarily with German princely families, served as the source of the paintings' arrival in Russia, numerous auctions were held in St. Petersburg - the sale of antiquarian objects and works of Art, where the masters demonstrated their works, finally, direct visits of artists to Germany were practised. Many Russian figures (scientists, writers, diplomats, travellers, artists) visited art museums, and young people who studied at German educational institutions also paid considerable attention to the arts. As a result, large private art collections of A.A. Bezborodko, Alexander Stroganov, Sheremetevs, Rumyantsevs and others were collected (Evangulova, 1987:68,69; Markina, 1995:12-19; Nikulin, 1987:10,11). A large part of them were samples of portrait, historical, landscape genres and still life. Still life was not the only genre in which animals were depicted. Another genre was the landscape, even though in Russia, it has not yet acquired an independent existence, as in the West. The names of many landscape painters, particularly the Dutch of the XVII Century: Paulus Potter, Aelbert Cuyp, and German mid-XVII Century: Jakob Philipp Hackert, Johann Klengel, were known in Russia. At the end of the Century, works by Russian landscape painters appeared, such as Semyon Shchedrin, who depicted domestic animals in nature. In the process of the formation of its own Animalier Art school, the emergence of such works was important. 
An essential property of the genre was the fact that the Animalier Art developed in the academic environment. The role of German artists in the emergence of a kind of genre, 'animal painting', in the organisation of the animalistic school in the Petersburg Academy of Arts (establishment of the 'animals and birds' class at the Academy of Fine Arts in 1765) was important. Here the principles of professionalism aimed at studying the subject were fundamental. At that time, it was the first professional school in which the training of drawing animals was held. Family workshops, 'handicraft cells', were typical for Western Europe as early as the XVI -XVII Centuries, where in addition to the master himself, there were two or four pupils and apprentices, the head was the father himself or the elder brother (not necessarily the most talented), under which worked close relatives (Libman, 1980:110-129). The reason for such small family-run schools in Germany was the small size of most of the art workshops and their financial weakness. According to certain patterns of drawings, sketches, 'drawn, painted and engraved', work was carried out, which became the school of young painters training. Hence, there was a commonality of traits in selecting a range of topics, motives, and drawing techniques. Probably, this method of education, which formed a certain stylistic similarity in the works, was acceptable; in particular, on Russian soil, it found a notable application. Grooth was the one who organised a whole generation of animal painters in Russia. Students studied the composition of the construction of animalistic scenes, the laws of colour gradations in the depiction of animals and the landscape, copied the works of the German artist, the 'court animal painter' J.F. Grooth, who worked in Russia since 1743. In this respect, Grooth completed all the details, and pictures representing a worthy role model (Figures 1,2). The Jubilee information book of the Imperial Academy of Arts of 17141914 says:'Animalier Grooth' had many excellent pupils imitating him" (The Jubilee information book of the Imperial Academy of Arts of 1714-1914. Compiled by Kondakov, 1915:454). Students were studying on the basis of samples. For this purpose, the Academy of Arts formed special 'embassies' and sent them to Europe to purchase artworks and various manuals for classes. .Painting works re also purchased from private collections. First, there were works by Western European masters in the museum, later Russian also: works by Professors and teachers, retired persons, as well as copies and original works of students of the Academy, which were the property of the Academy (Krylova, 1986:65,66).

In the XVIII Century, the creation of copies, in particular animalistic, was also dictated by the need to educate and spread this kind of Art. In addition, the demand for copies was further enhanced by general aesthetic illiteracy. The originals for their creation were works by foreign painters, which were most consistent with the holistic notions of artistic fashion and 'modernity'. 


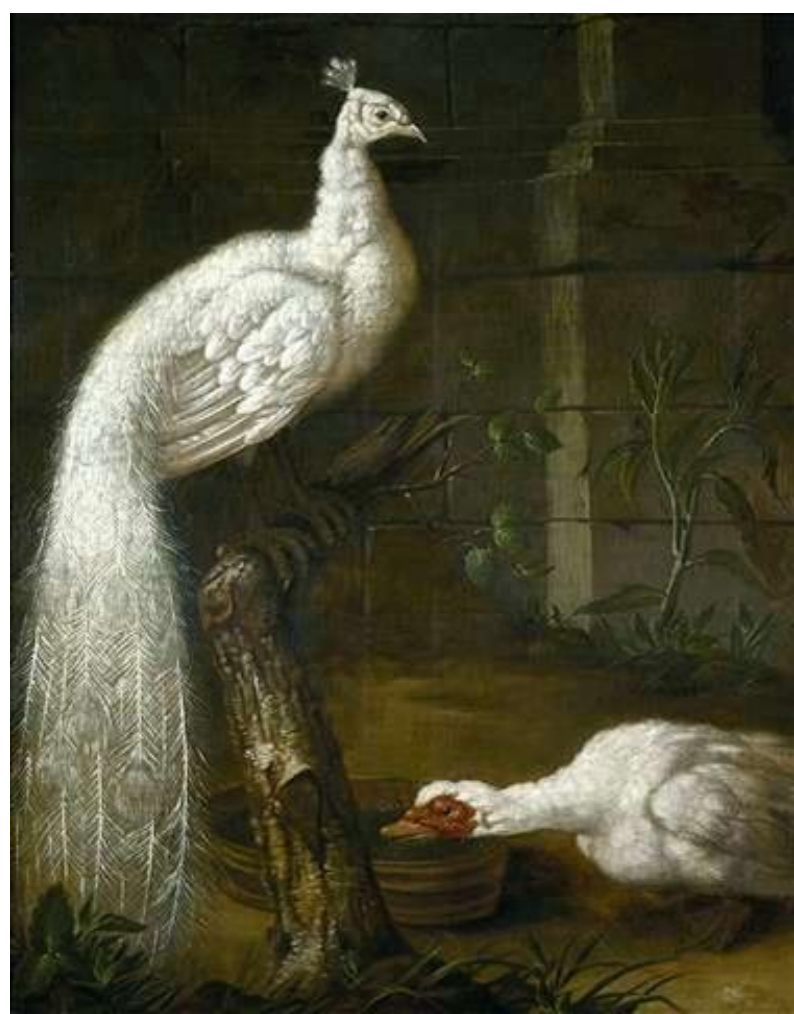

Figure 1: J.F. Grooth- A Goose and a White Peacock, 1786.

Source: http://artpoisk.info/artist/groot_iogann_fridrih_1717/gus_i_belyy_pavlin/

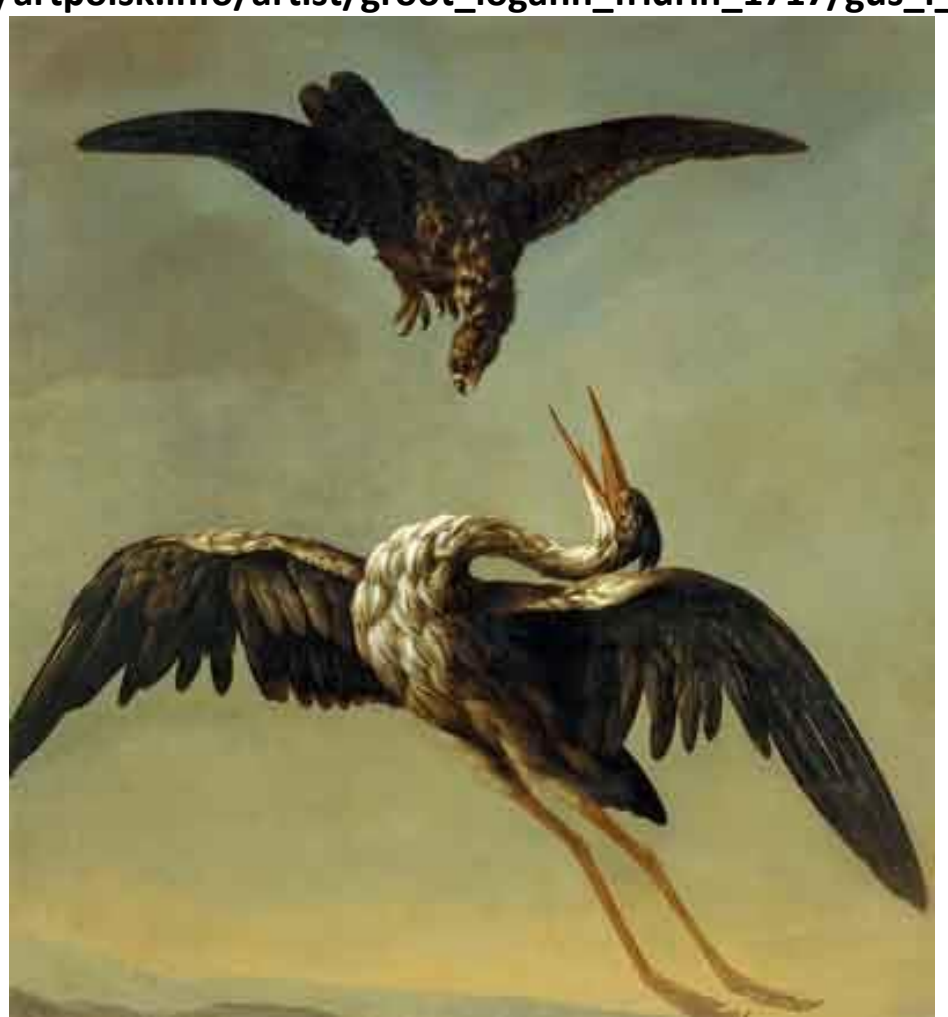

Figure 2. J.F. Grooth-The Kite and the Heron, 1786.

Source: http://www.nasledie- rus.ru/podshivka/pics/7203-pictures.php?picture=720319 


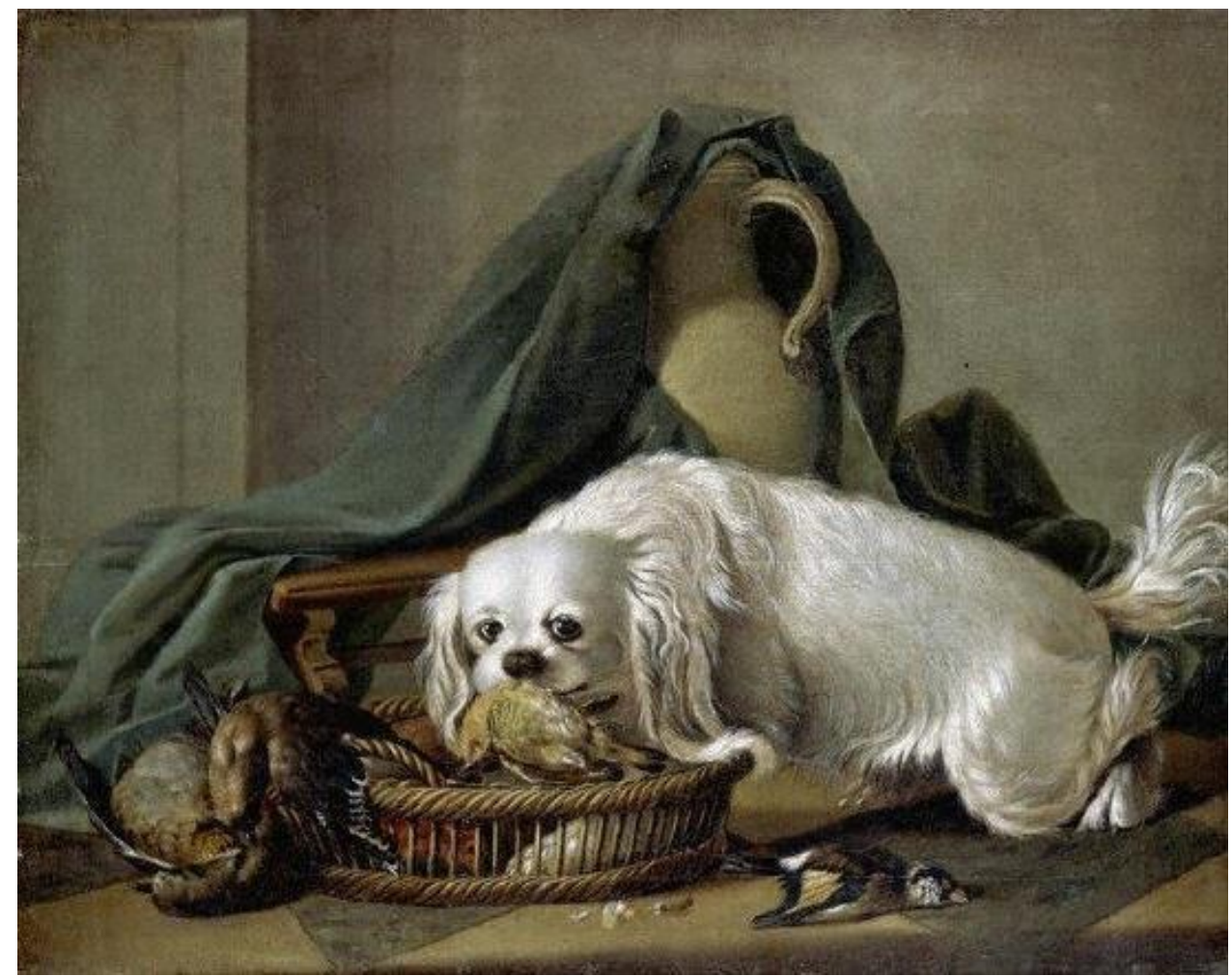

Figure 3: Alexander Dobryakov-The Dog at the Basket with the Bat Game Source: https://otvet.mail.ru/question/206420304

Those students of Grooth who reached a certain level of skill in their artistic activity received ranks and were appointed heads of other classes at the Academy of Arts (Collection of Materials from the History of the Imperial Petersburg Academy of Arts for a Hundred Years of Its Existence. 1864). The picturesque talents of Grooth, Quadal, Knappe, the graphic heritage of Klauber and the Russian disciples contributed to the appearance of a full-scale easel animalistic painting and engraving (Figure 3).

So, for many years of existence of the 'animals and birds class', samples of Animalier Art were created in the workshops of the Academy of Arts, which fully corresponded to the tastes and needs of the society of that time.

It should be said that in other European academies of Europe, such classes are not met. In Germany, artists of different genres and directions worked in widespread private and family workshops, where they received the necessary education and training for their mastership. In the late XVII - early XVIII Century, we see the opening of many artistic academies in Italy, France, Germany, England, where training was based on the system of accepted classicism norms. Following the model of the Royal Academy of Painting and Sculpture in Paris (1648), where the rules of the 'Grand maniere' style were worked out, academies were founded in many cities of Germany: in Berlin, Munich, Dusseldorf, Nuremberg, Stuttgart. Animaliers who trained in craft workshops or academies received the necessary skills in drawing. Their training relied on the accepted samples and norms, the stylistic devices of Western European painting of the XVI-XVIII Centuries, including animal images. There were a large number of paintings in the German collections, and the number of schools also were not too small. Therefore, there was no shortage of either model for drawing or teachers. In addition, at that time Europe was already rich in menageries and zoos, on the basis and material of which the Animaliers drew plots for their paintings and honed their craftsmanship.

Thus, the need for 'animal' images in Russia was determined by the cultural features of the era, particularly the receptivity of Russian Fine Arts to new themes and plots. Animalistics entirely 
fits into the genre structure of the XVIII Century. The soil for the Russian Animalier genre has formed in its characteristic themes and images and in various Fine Arts. Such a theme throughout the XVIII - XIX Centuries was the 'hunting genre' and the interpretation of 'hunting animals', which in many ways determined the development of Animaliers Art with its plot orientation, love for scenes of Russian life. The works were created with a great knowledge of the matter, they can be called the Encyclopaedia of Russian Hunting. At the same time, they were not the way to admire animal instincts, as it was in the West. For all the thematic and stylistic similarity, Russian Animalier Art did not have a special interest in treating purely animal scenes, for example, a fight of animals; bat game also did not often appear in Russian still lifes. Allegorical images were not dominant, yet there was another thing: the focus on the animal, the transfer of its character. A sketch of elegant animal forms and the manifestation of its plastic movements, an image in the landscape, an interest in sketches of everyday life; that's what the masters were interested in.
If the XVIII Century Animalier Art was mostly picturesque (Animal Painting), then the first half of the XIX Century was the second stage in its development marked by the development of Russian animalistic sculpture. And here, it was not an isolated phenomenon. The theme of the Rider, both in sculpture (P.K. Klodt) and in painting and graphic arts (K.P. Bryullov, K.P. Beggrov), met the principles of Academic Art. The thematic range of animalistic works defined in the XVIII Century, including the theme of hunting, still life with animals (bat game), the image of domestic and wild animals in the landscape, was embodied in the Russian Fine Arts of the XIX Century. Some of them, for example, hunting theme with the image of 'hunting animals' remained popular throughout almost the entire XIX century. Its motives can be seen in painting and sculpture. New landmarks in the genre aimed at the nature portrayal, different phenomena of life were designated. Then a horse began to act as the leading character, who was actively involved in landscape, every day, historical-and-battle compositions figured in a graphic, pictorial, sculptural 'portrait' (Figures, 4, 5,6,7).

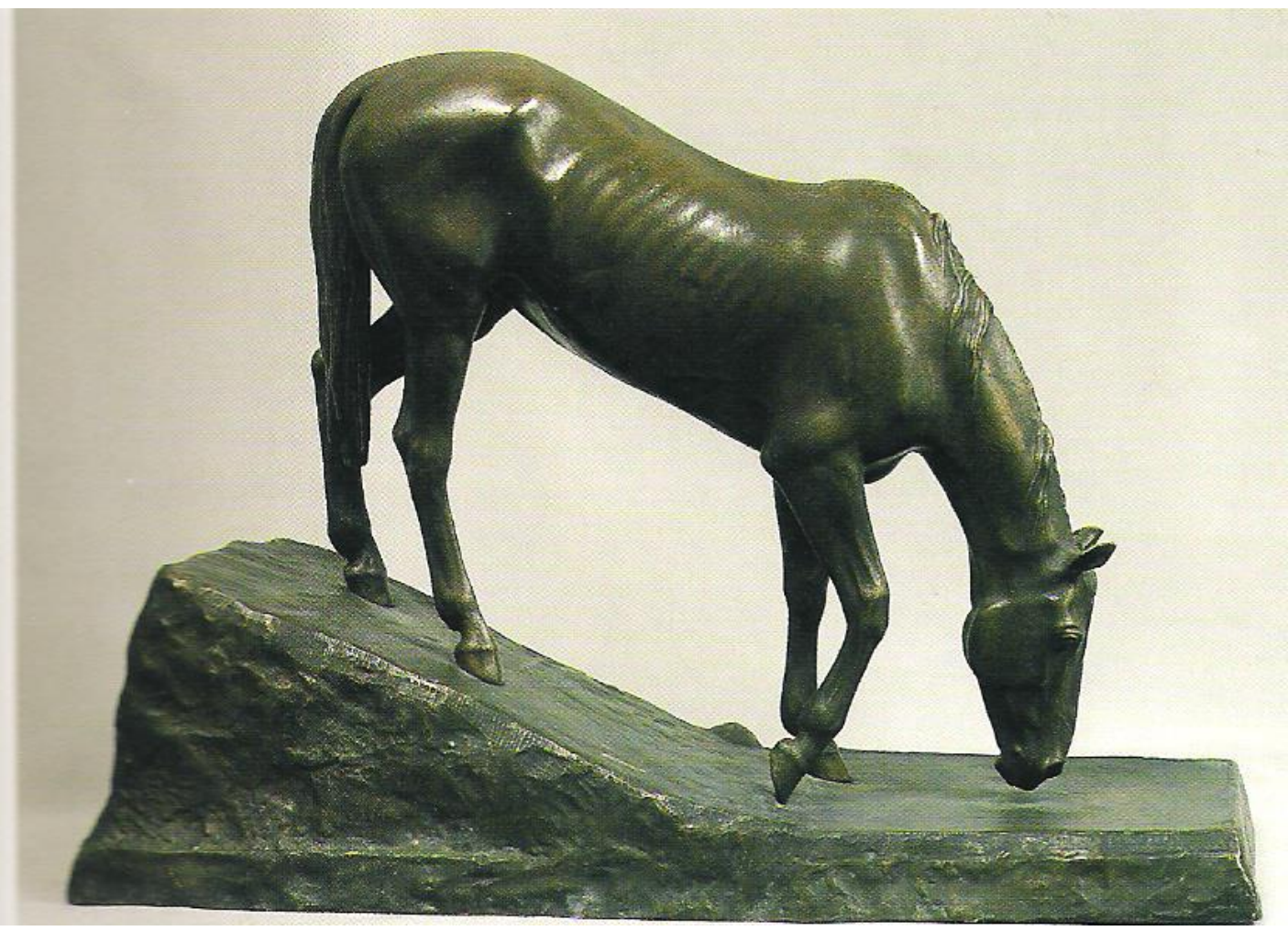

Figure 4: P.K. Klodt. Horse at Watering Hole, 1850. Bronze

Source:https://auction.ru/offer/loshad_na_vodopoe_kasli_1903_god_skulptor_p_klodti129713097453416.html 


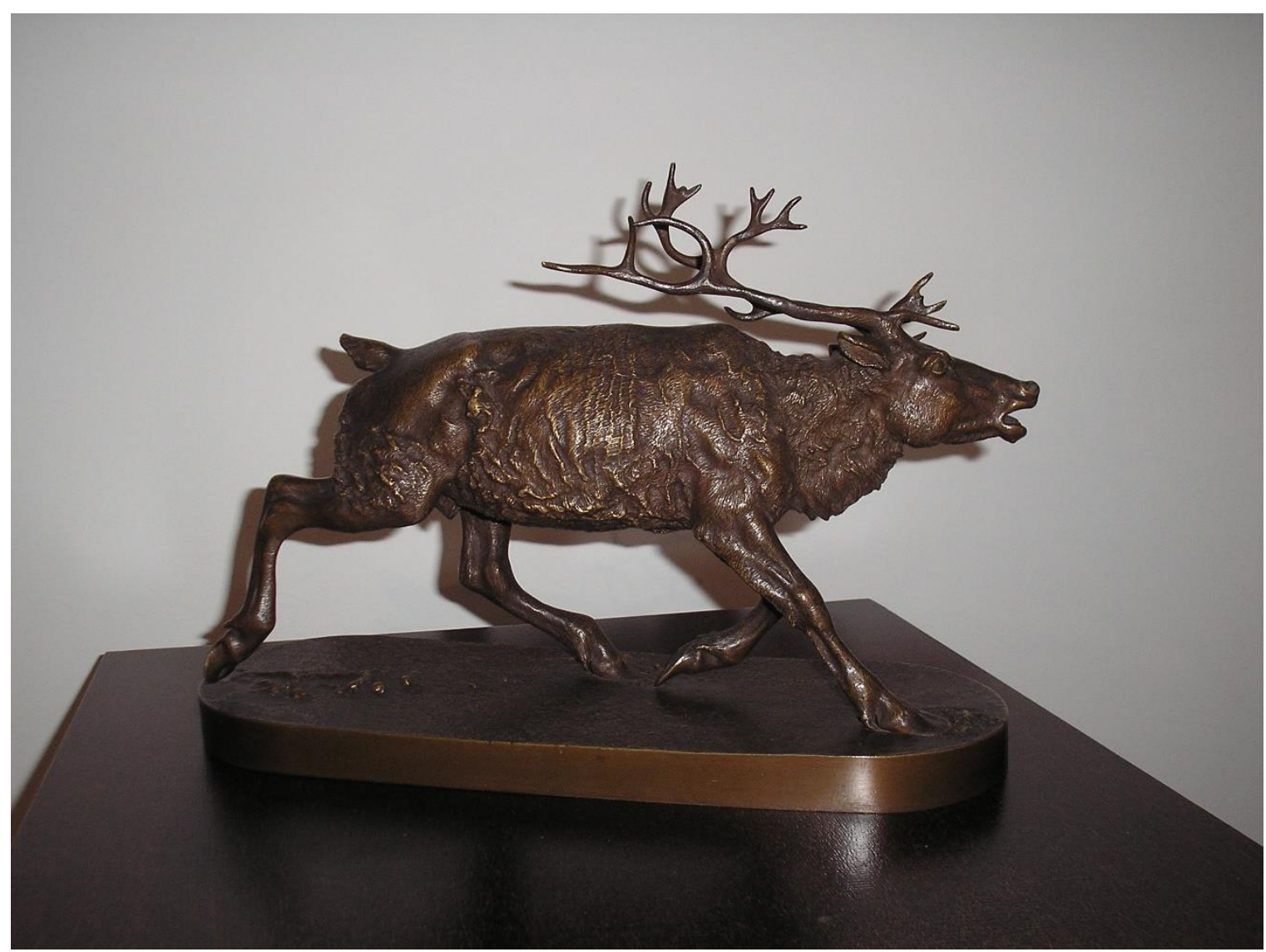

Figure 5: N. I. Liberich-The Deer of the 1860s, Bronze Source: http://egorovgallery.ru/catalog/russian-

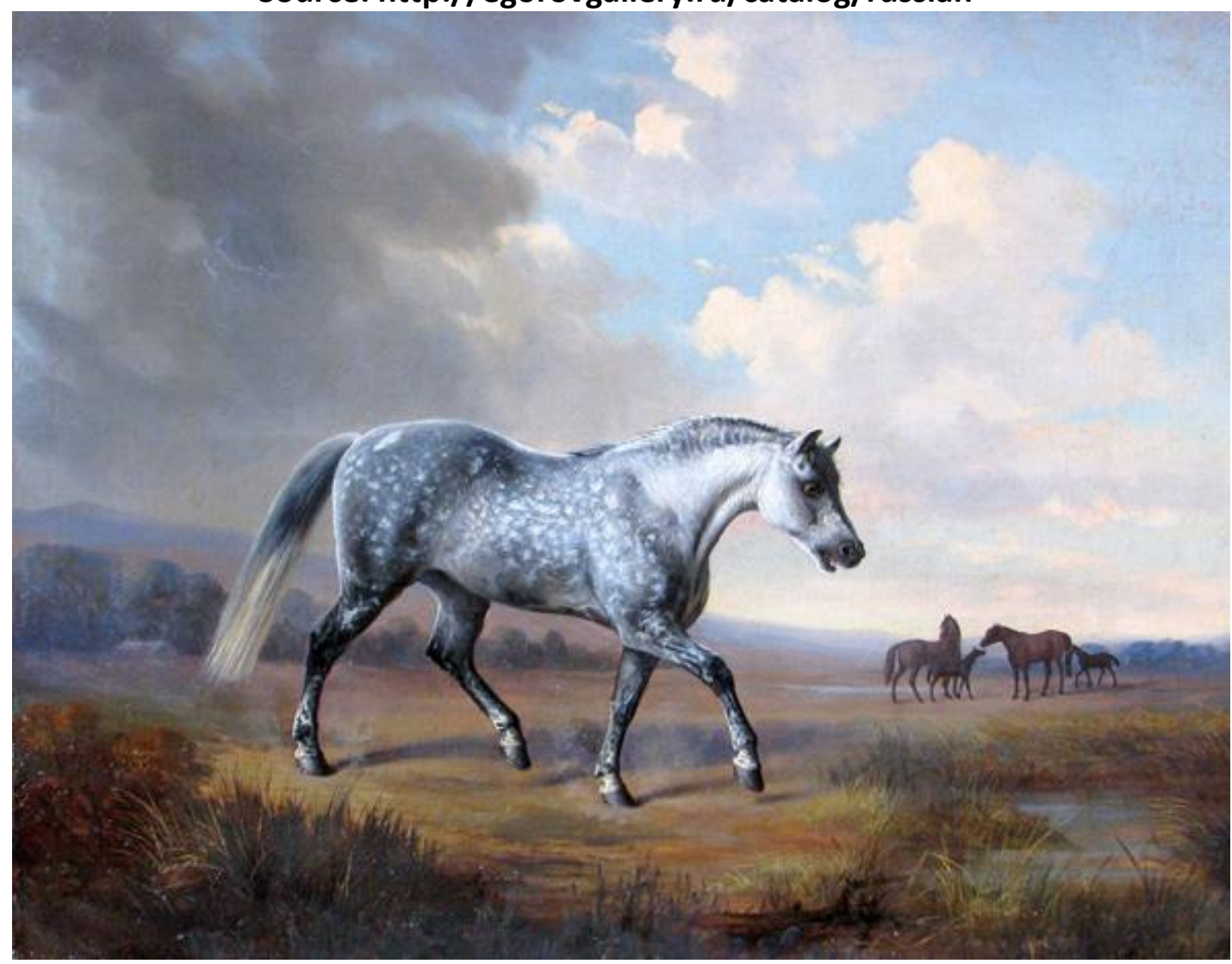

Figure 6: A. P. Schwabe- A Grey Trotting Horse on the Move, 1859 Source: https://vk.com/photo-59848835_457256883 


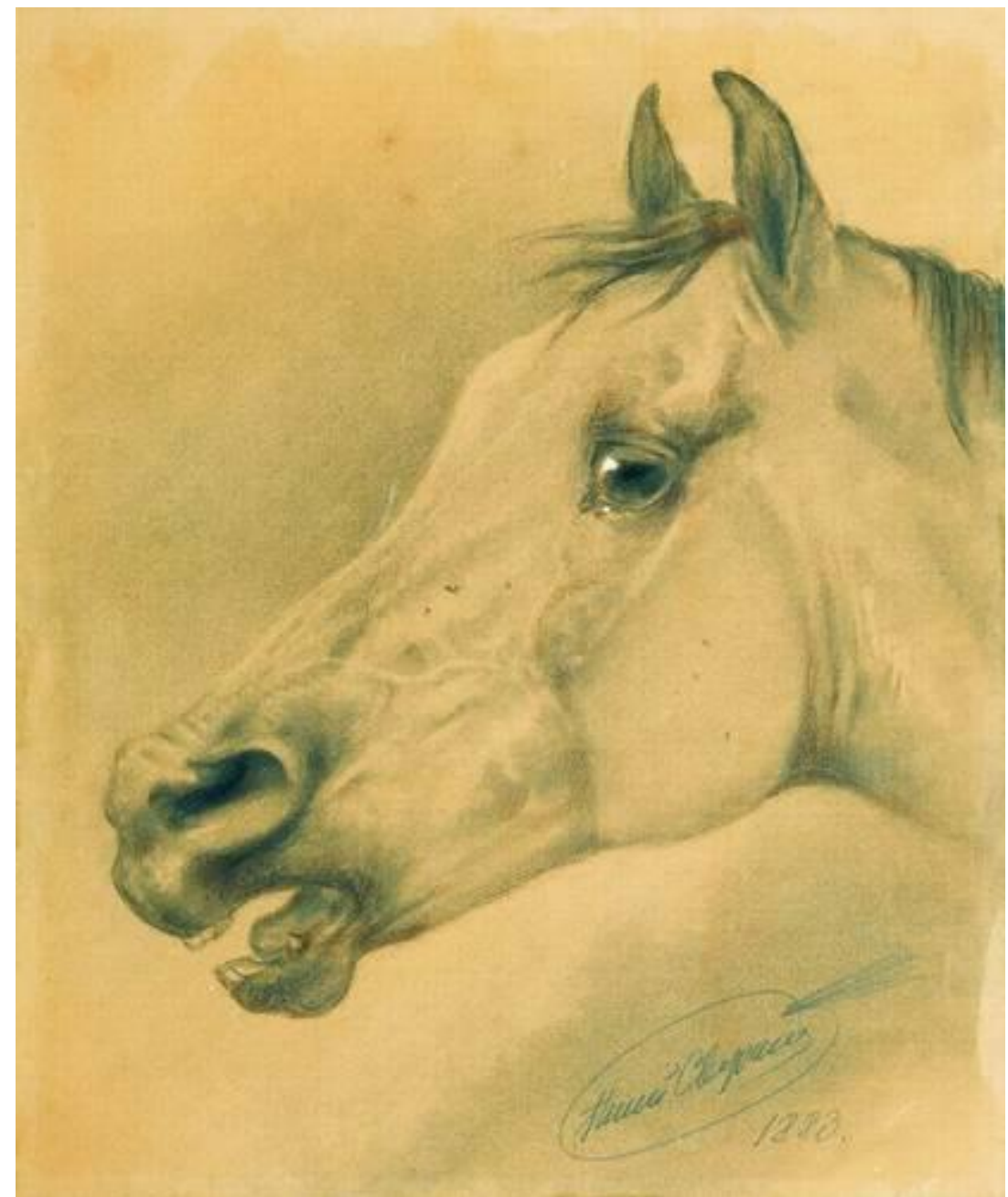

Figure 6: A. P. Schwabe- A Grey Trotting Horse on the Move, 1859 Source: https://vk.com/photo-59848835_457256883

Then the main themes and images appeared in the system of academic education in a certain artistic technique and style framework. A look at the horse as an ideal specimen has formed in the first half of the XIX Century the pictorial preferences associated with the line of the ceremonial horse portrait (a rider) with a deep tradition in European and Russian Art. The horse defined a pictorial iconographic scheme of 'hippique' images of the time that fitted the concept of high Art, whose ideas the official painting art reflected. As Ryazantsev rightly pointed out, "similarity in the ceremonial image was approved by law" (Ryazantsev, 1994:125).

In academic Art, the horse was revered as an aesthetic model, the standard of beauty. While the sublime beauty of wildlife and animals inhabiting it were the motif of many works by German, English, French 'romantic animaliers', where even domestic animals (a dog, a horse) were sometimes immersed in an atmosphere of grandeur, the image of a horse against this background looked a little bit prosaic in Russian animalier art which has gone away from romanticism towards greater realism. So, the muscular, slender, healthy bodies of the horses of the Russian artist A.O. Orlovsky, their general impressive representative appearance fully fit into the objectives of the European romantic picture. At the same time, the artist was more concerned about how the horse is depicted, whatever breed it is, Turkish or Arab, and perplexed about what for the Vernet's horses were praised. In his opinion, they were "too elegant, docile, looking like a girl tightened in a corset" (Kalaydovich, 1860:183).

The second half and the end of the XIX Century show us a completely different version of the 'portrait' image associated with the flowering of the 'hippique genre' in Russia, which dates back 
to the $1860-80$ s of the XIX Century. This is not surprising because Russia surpassed all other countries in terms of their number and variety of breeds coming up to more than fifty. "Not by millions, but by tens, and maybe hundreds of millions, can be assessed the raise of value level of horses in Russia", concluded V. Koptev, a researcher (Koptev, 1876:20). P. Pertsov pointed out this fact to characterise the peculiarity of Russian reality that had not known yet the railroads and weeded an equine culture for its already multi-complex life(Pertsov P.P., Russian State Archive of Literature and Art, archive 710 , list of files 1, item 14).

At this time, in connection with the growth of equestrian factories and interest in the racetrack business, the so-called 'horse-breeding portrait' was getting widespread, depicting famous racehorses of different breeds (Orlov, Arab, Akhal-Teke). Breeders ordered picturesque 'portraits' of horses of their factory and predetermined the principles of interpretation of the 'horse-breeding portrait': the skill to display the breed, and convey the model's similarity features of the horse's exterior. Reflecting the preferences and tastes of equestrian factories owners, such a 'portrait' was their pride; it decorated their cabinets and was demonstrated to the guests. Representatives of different levels of professional training worked on such an issue: from local painters who represented an "nonacademic" line up to artists of the highest class. Among them were notable masters: A.P. Schwabe, N.E. Sverchkov, V.A. Serov, P.O. Kovalevsky, N.S. Samokish, S.A. Vinogradov, and others. In the second half of the XIX Century, being carried away by the variety of horse breeds, the sculptors showed a craving for the transfer of the fullness of the animalistic image features, which manifested itself in the detailed development of the plot composition and careful forms modelling. A similar interpretation of the image can be observed in the West due to the extensive use of bronze enabling detailed fixation of nature. Therefore, aa criticalmoment was the flourishing of the bronze casting that unfolded in Russia in the second half of the XIX Century and beneficially affected the animalistic image, educating the artistic taste and contributing to its spread. Focusing on highquality samples of French bronze animalier art (P.J. Mene, J. Moigniez, A.-L. Barye, E. Delaplanche, A. Dubucand, A.A. Arson, and others), Russian sculptors successfully comprehended the properties of this material, putting the development of Animalier Art to a new level. This material, traditional for European sculpture of the XVIII-XIX centuries, was mastered by the first Russian Animalier Sculptor, P.K. Klodt, at all stages of the work. In 1838, after the death of V.P. Yekimov, he headed the 'Foundry House' of the Academy of Arts, which by that time already had fruitful traditions. N. Rubtsov (Rubtsov, 1950:38,39,42), I. Ryazantsev, (Ryazantsev, 1984:133), A. Romm (Romm, 1948:27) pointed to his mastery of the artist, who succeeded to study the complex process of casting, requiring at each step a delicate calculation, attention and great accuracy. Comparing Klodt with Russian masters of the second half of the XVIII Century who mostly worked with marble, the authors emphasised the importance of bronze for him, which became a recognised material of the sculpture in the first and second halves of the XIX Century. It is significant that for the first time in the history of Russian Art, Klodt, the Animalier, became a figure caster, although the horse was found in bronze sculptures by A. Martelli, M.I. Kozlovsky. Observation and study of the model, this universal approach to the image in Animalier Art, successively manifested in Klodt's work, was taken as the basis for creative solutions by Lansere and other Animalier Sculptors of the second half of the XIX Century. Assuming some influence of realistic painting of the second half of the XIX Century on animalistic sculpture, the historical and documentary cycles of $\mathrm{V}$. Vereshchagin's paintings and his ethnographic types are recalled. V. Stasov wrote about the famous battle painter and found in his work features close to Lansere: "These two so different artists converge on one thing," the critic noted, "on the love of true, real, simple, unadorned truth and devotion to those only plots that, in fact, exist and were seen with their 
own eyes." (Schmidt I.M., Russian State Archive of Literature and Art, archive 652, unit 718).

It is hard to disagree with Stasov. It was the living nature that became the source of the animalier sculptors thoughts, and to a lesser extent it was the modern painting. It seems that the masters did not retreat a single step from nature. The detailed analysis characteristic of their method was intended to show the truth of life consisting in its concrete fixation. These were the features of the 'hippique genre' of the second half of the XIX Century, significantly distinguishing it from the antecedent time. In fact, we can talk about the birth of the Russian Animalier Sculpture school in the XIX Century, the masters of which showed a unified focus of artistic aspirations, a common passion for foundry and knowledge of this complex craft, which eventually formed the integrity of the creative method within the boundaries of existing styles and traditions, which contributed much to flourishing of the genre.

A similar process was observed in Russian graphics. Not an exemplary engraving, repeating a picture that was common in many European schools, but in most cases drawing by hand determined the graphic skill of Russian artists. Nevertheless, it is necessary to recognise that the 'hippique genre' was a separate page of Russian Animalier Art, where an integral image was formed. It clearly showed the typical features expressed in the storyline and in the interpretation itself. The famous Masters concentrated their efforts here.

\section{Conclusion}

As a result, we note that the image of animal models in various scenic genres of the XVIII Century testified to the growing popularity of the Animalier Art, which peaked in the middle and second half of the Century. In the XIX Century, when animals increasingly became a necessary part of the historical, battle, every day, landscape and portrait paintings, their compositional value and the 'flavour' that they introduced into the narrative characterising the way of life and the historical situation, were noted. By the example of a horse, which became the main, almost the only hero, the characteristic features of an animalistic image were worked out. We can come to a conclusion about the formed traditions. In accordance with the historical and cultural context of the epochs, plot-thematic preferences, views on the Art of depicting animals, and the figurative system of the works themselves were gradually changing, which led to the emergence of new artistic principles. The understanding of the model as a sensually and rationally comprehended part of nature remained unchanged. Animalier Art solved these problems at every stage of its development. Having emerged from the needs of a society of the XVIII Century in the realisation of scientific aspirations in the sphere of cognition of living nature, in the subsequent time, having inherited these features, in different types of Fine Arts it demonstrated its significance from the cognitive and artistic point of view and the historical expediency of its existence.

We attempted to turn the readers' attention to the natural expediency reflected in the Animalistic Art of the periods under consideration and to point out an essential factor in its formation and subsequent development. Thus, the role of Animalism was that it was able to recreate the picture of the natural world that was associated in a broad sense with the 'picture of the world' during two historical periods (XVIII XIX). On this path, acting in its independent genre quality, as the modality of the new thematic reality, the genre beginning of which found expression in various types of Fine Art, played an unquestionable role in the broad worldview sense as a value factor of the interaction between human and nature and, narrower, as the graphic theme of time. Focus on animalistic in its genre qualities allowed to interpret this phenomenon as new in the light of what was already known about the Art of pictures of animals. This new understanding of the problem put forward the formulation of the problems that have not been discussed so broadly. We are talking about the formation of traditions in the national aspect. On the background of existing in ancient times and the West a long tradition of depicting animals, Russian Animalier Art relied on Western samples 
on the first stage of its formation, then developed in parallel with other national schools and eventually formed its own traditions that are still relevant nowadays. It took root in a genre quality, acquiring a visual and concrete form based on the principle of reliability. Wherever it manifested itself, each time, the artists showed a commitment to displaying a particular model.

Along with some idealisation that could be found in Animalism, masters skillfully reproduced the natural qualities of animals. Of course, as part of a review article, it is not possible to consider and tell about all genre properties of Russian animal art. Nevertheless, in the context of the existing diverse literature on animal art, focused largely on the history of methods of depicting animals and the interpretation of classical samples, the genre independence of Animalism seems to be a potential area for further consideration. We could see it by the example of the artistic image of the 18th and 19th Centuries. In the future, there will be some historical metamorphoses, which will also affect Animalism. However, from the formed genre structure, lets us evaluate Russian Animalier Art as a characteristic structural pictorial phenomenon of time. The Animalier Art in the general European context is a special reality engendered by the national peculiarities of Russian culture.

\section{References}

Andreev A. N. (1857). Painting and painters of the main European schools, St. Petersburg: Ed. By O. Wolf, pp. 17.

Baker Steve (2000). The Postmodern Animal. Reaktion Books. pp. 208

Beime B. (2015). Hogarth's Art of Animal Cruelty: Satire, Suffering and Pictorial Propaganda. Springer, pp.144.

Giorgi R. (2008). European Art of the Seventeenth Century. Getty Publications. pp.383.

Evangulova O.S. (1987). Fine arts in Russia in the first quarter of the XVIII century. The problem of formation of the artistic principles of the New time, pp. 68, 69.
Kalaidovich N.K. Alexander Orlovsky, Illustration 1860 No. 109, pp.183.

Kalof L. (2009). A Cultural History of Animals in the Renaissance, Berg, pp. 261.

Kopaneva N.P. (2006). Walk through the Paper Museum of the Imperial St. Petersburg Museum Science First Hand No. 3, pp.58-77.

Koptev V.I. (1876). Eulogy. Centenary anniversary in honor of Count Alexey Grigorievich Orlov-Chesmensky in memory of the breed of horses, riding and trotting, founded by him in 1775 . Moscow, University printing house, pp.20.

Krylova L.N. (1986). Copies, original works by Russian academician artists of the XVIII century and standards for copying at the Academy of Arts. Russian painting of the XVIII century. Research and restoration.Collection of scientific papers. Moscow, pp. 65, 66.

Libman M.Ya. (1980). Dürer and his workshop (the process of work and methods of teaching). From the history of classical Art of the West. Collection of articles. Moscow, pp.110-129.

Lippincott Louise, Andreas Blühm. (2005). Fierce Friends: artists and animals, 1750-1900.

Merrell. pp.160.

Markina L.A. (1995). G.C. Grooth, L.C. Pfandzelt and their role in the formation of the collection of Tsarskoe Selo, the first picture gallery in Russia. Private collecting in Russia. Moscow, pp. 12-19.

Markina L.A. (1999). Portraitist G.C. Grooth and German painters in Russia in the middle of the XVIII century. Moscow, pp. 109.

Morton Mare G., Bailey Colin. (2007). Oudry's painted menagerie: portraits of exotic animals in eighteenth-century Europe, Getty Publications, pp. 168.

Nikulin N.N. (1987). German and Austrian painting of the XV-XVIII Century. Catalog. The State Hermitage Museum. Iskusstvo, 10, 11

Petrov V. (1864). On animal painting in general and especially in Russia. Northern lights. Russian art album. C-Petersburg, vol. 3. p.19. 
Pertsov P.P. Sverchkov in Prilepsky collection. Article. Butovich Yakov Ivanovich. Materials to the collection about the artist Nicolay Yegorovich Sverchkov. 1922-1925. Russian State Archive of Literature and Art. RGALI, Archive 710. List of files 1 , item 14. Sheet 39.

Romm A.G. (1948). Peter Karlovitch Klodt, Moscow-Leningrad, Iskusstvo, pp.27.

Rovinsky D.A. (1895). A detailed dictionary of Russian engravers of the XVI - XIX centuries. St. Petersburg. The Imperial Academy of Sciences Press. SPB, pp.720.

Rubtsov N. N. (1950). V. P. Ekimov and P. K. Klodt are outstanding masters of Russian artistic casting. Mashgiz, pp. 38, 39, 42.

Ryazantsev I.V. (1984). P.K. Klodt and some problems of Art of the first half of XIX century. Works of Academy of Arts of the USSR, Issue 2. Moscow, pp.133.

Ryazantsev I.V. (1994). Russian sculpture of the second half of XVIII - early XIX century.

Moscow, pp.125.

Schmidt I.M. (1954). Evgeny Alexandrovich Lansere. 1848-1886. Moscow, Art, pp.30.

Schmidt I.M. (1954). Evgeny Alexandrovich Lansere. Russian State Archive of Literature and Art RGALI, Archive 652. Unit 718. Sheet 4.
Sytin, A. K. (2003). The husband of the things of herbs in the search for the vigilant, Nature. No. 6. P. 93.

Tikhonov A. (2004). Swiss Petersburg. Russkoye Iskusstvo. 2 .pp. 26

Toynbee Jocelyn M. (1886). Animals in Roman life and Art. Johns Hopkins University Press, pp.431.

Urvanov I. F. (1793). A short guide to cognition of drawing and painting of historical kind, based on speculation and experiments. Composed for students by artist I.U, SPB, pp.45, 48 .

Waldau P, Patton K. A (2006). Communion of Subjects: Animals in Religion, Science, and Ethics. Columbia University Press, pp.720.

Wemess Hope B. (2006). Continuum Encyclopedia of Animal Symbolism in World Art. A\&C Black, 2006, pp. 476.

Wolloch N. (2017). Subjugated Animals: Animals And Anthropocentrism in Early Modern European Culture. Prometheus Books, pp.280.

\section{Conflict of Interest}

I hereby declare that I have no conflict of interest

\section{Acknowledgements}

This study has been supported by The RUDN University Strategic Academic Leadership Program 